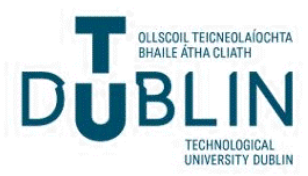

Technological University Dublin

ARROW@TU Dublin

\section{Public Goods and Public Policy: What is Public Good, and Who and What Decides?}

\author{
Ellen Hazelkorn \\ Technological University Dublin, ellen.hazelkorn@tudublin.ie \\ Andrew Gibson \\ Technological University Dublin, andrew.gibson@tudublin.ie
}

Follow this and additional works at: https://arrow.tudublin.ie/aaschmedoth

Part of the Education Commons

\section{Recommended Citation}

Hazelkorn, E., \& Gibson, A. (2017). Public goods and public policy: what is public good, and who and what decides? Working paper no. 18 (2017). Centre for Global Higher Education.

This Working Paper is brought to you for free and open access by the School of Media at ARROW@TU Dublin. It has been accepted for inclusion in Other by an authorized administrator of ARROW@TU Dublin. For more information, please contact arrow.admin@tudublin.ie, aisling.coyne@tudublin.ie,gerard.connolly@tudublin.ie.

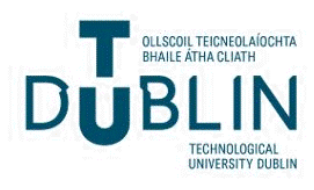


CENTRE FOR

CLOBAL

Hich

EDUCATION

Centre for Global Higher Education working paper series

\section{Public goods and public policy: what is public good, and who and what decides?}

\section{Ellen Hazelkorn and Andrew Gibson}

Working paper no. 18

May 2017 
Published by the Centre for Global Higher Education, UCL Institute of Education, London WC1H OAL

www.researchcghe.org

(c) Centre for Global Higher Education 2017

\section{ISSN 2398-564X}

The Centre for Global Higher Education (CGHE) is the largest research centre in the world specifically focused on higher education and its future development. Its research integrates local, national and global perspectives and aims to inform and improve higher education policy and practice. CGHE is funded by the Economic and Social Research Council (ESRC) and the Higher Education Funding Council of England (HEFCE), and is a partnership based at UCL Institute of Education with Lancaster University, the University of Sheffield and international universities Australian National University (Australia), Dublin Institute of Technology (Ireland), Hiroshima University (Japan), Leiden University (Netherlands), Lingnan University (Hong Kong), Shanghai Jiao Tong University (China), the University of Cape Town (South Africa) and the University of Michigan (US).

The support of the Economic and Social Research Council (ESRC) and the

Higher Education Funding Council of England (HEFCE) is gratefully acknowledged. 


\title{
Public goods and public policy: what is public good, and who and what decides?
}

\author{
Ellen Hazelkorn and Andrew Gibson
}

Contents

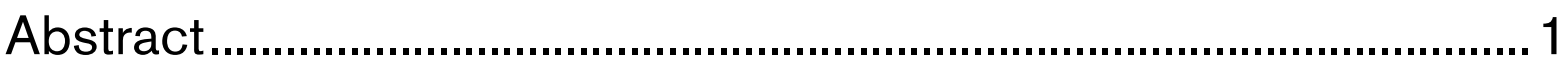

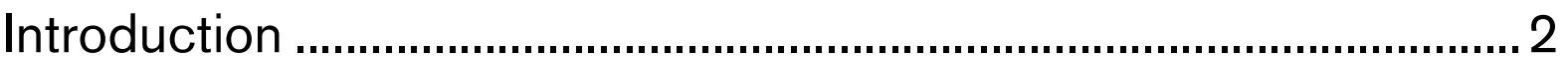

1. Negotiating the public good ............................................................. 4

2. Re-defining and re-regulating the 'social contract' and

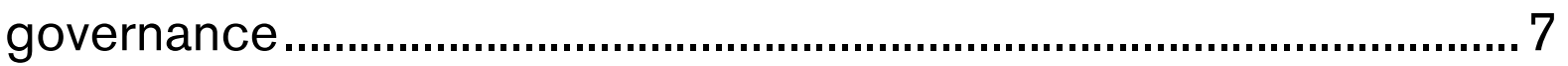

3. System steering: Ireland and the Netherlands ........................... 11

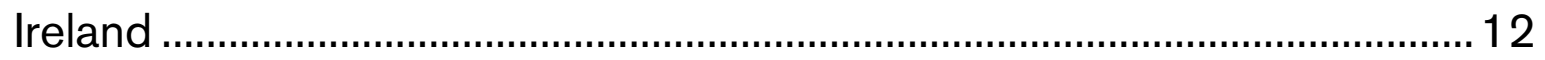

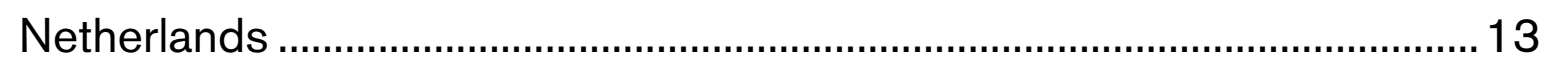

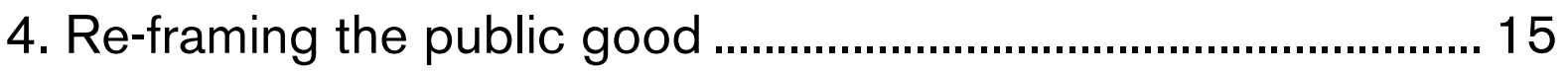

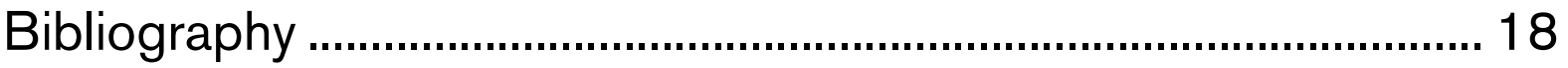




\title{
Public goods and public policy: what is public good, and who and what decides? ${ }^{1}$
}

\author{
Ellen Hazelkorn ${ }^{2}$ and Andrew Gibson ${ }^{3}$
}

\section{Abstract}

Higher education is usually seen as serving the public good, especially when funded directly by the state, and because of the 'social benefit efficiency gains and potential equity effects on opportunity and reduced inequality' (McMahon, 2009, p. 255). Calhoun (2006, p. 19) argues that public support for higher education is only given and maintained according to its capacity, capability, and willingness, to 'educate citizens in general, to share knowledge, to distribute it as widely as possible in accord with publically articulated purposes'.

So what is the public good and what defines it? Recent years have seen many governments adopt the format of a national strategy or development plan for higher education - setting out national objectives. Similarly, many governments (e.g. Ireland, Netherlands, Hong Kong, Finland, New Zealand) are adopting the policy tool of performance agreements or compacts to better align higher education institutions (HEls) with the national objectives, involving identification of appropriate performance management and indicators (Benneworth, et al., 2011; de Boer, et al., 2015). The process by which national objectives are determined varies but may involve a group comprising national and international 'experts', sometimes using consultation mechanisms (open or limited). The concept of public good has played a significant role in (re)positioning higher education over recent years - especially in response to growing demands for greater accountability for all public organisations but also in response to specific concerns about growing higher education access/participation, costs/debt, graduate employability/unemployment, and social/economic impact. This paper takes a practical approach - both in relation to asking 'what is the public good' and 'who defines it' - by looking at how different countries are approaching the issue. 
Institutions of higher education are conducted for the common good and not to further the interest of either the individual teacher or the institution as a whole. The common good depends upon the free search for truth and its free exposition. Academic freedom is essential to these purposes and applies to both teaching and research. (Statement of Principles on Academic Freedom and Tenure, AAUP, 1940)

The further expansion of higher education is inevitable and essential if we are to fulfil our aspirations as an innovative and knowledge-based economy, and we must ensure that this happens within a coherent policy environment that serves the advancement of knowledge, wider national development and the public good. (DES, 2011, 33)

\section{Introduction}

Today, as the debate about widening participation, employment and graduate attributes, and the importance of higher education and research intensifies in many countries, the public is asking whether its interests are being served. Those interests inevitably vary depending upon who is asked - students, parents, employers, the media, politicians, etc. US surveys show public concerns about credential relevance and cost are high on the agenda with many people unhappy with levels of accountability (Public Agenda, 2016). An AAC\&U survey showed a gap between how students and employers viewed career readiness (Jaschik, 2015). Another manifestation is relative public indifference about higher education, beyond general approval in the abstract (HEFCE, 2010). This suggests that while there is a broadly positive perception of higher education, the public is uninformed of its many functions and contributions. Reports from both the US and UK argue that the public views higher education as too self-serving, rather than being concerned with providing students with a quality education or issues beyond the campus (Immerwahr and Johnson, 2010; Lumina, 2013; Williams, 2016). Similarly, Ireland has witnessed a war-of-words about the quality of its graduates. While there is a consistent view that a college education is important and highly valued (BSA, 2013; Ipsos MORI, 2011), 83 per cent of European students '(strongly or rather) agreed that independent reports on the quality of universities and programmes would help students to decide where to study', and an equally high proportion would like to be involved in quality reports and rankings (Eurobarometer, 2009, 5).

Despite popular endorsement of higher education, it is not a popular political sell against competing demands from elsewhere in society, e.g. early schooling through to secondary schools, health and social services. The recent Brexit vote and the US presidential election pick up on the uncertainty of higher education's impact and relevance, the role of experts as elites, and the extent to which single-minded pursuit of global reputation has generated schisms between local, regional, national and global responsibilities (Goodwin, 2016; Kirk and Scott, 2016). Universities are often 
seen as 'islands of affluence, self-importance, and horticultural beauty in seas of squalor, violence, and despair' (Harkavy quoted in Boyer, 1996, 19). These tensions highlight an underlying message that public support for higher education is only given and maintained according to its capacity and willingness to 'educate citizens in general, to share knowledge, to distribute it as widely as possible in accord with publically articulated purposes' (Calhoun, 2006, 19).

In recent years, the concept of public interest - or public good - has played a significant role in shaping what the university and the academy do, but also how they position themselves in response to this growing uncertainty and demands for greater accountability. While these calls affect all public organisations, there are specific issues for higher education regarding concerns about access and participation; costs, affordability and debt; employability and graduate attributes; and relevance, and social and economic impact and benefit. Traditionally, defining and asserting the value and quality of higher education has been a function of the academy itself. There has been a strong history of civic and land-grant universities prompted and supported by the state, not just in the UK and US (Goddard et al., 2006) but elsewhere. However, there is an underlying assumption that because (public) universities represent the public good, their actions and outcomes ipso facto are in the public interest. Today, that supposition is coming under pressure. The pendulum is moving from academic self-accountability towards stronger and broader ways of asserting social and public accountability. So, what is the public good, and who or what defines it?

Recent years have seen many governments adopt the format of a national strategy or development plan for higher education as a means of setting out national objectives - or arguably shaping the 'public good'. Some governments (e.g. Ireland, Netherlands, Hong Kong, Finland, Ontario, New Zealand) are adopting the policy tool of performance agreements or institutional compacts to better align HEls with the national objectives. In some instances, specific targets have been set. This involves identifying appropriate performance indicators and management (Benneworth et al., 2011; de Boer et al., 2015). While there are historic differences between centralist and devolved governance systems, these processes are in effect an attempt by governments to set out, as unambiguously as is politically possible, the responsibilities of HEIs to society. The process by which national objectives are determined varies but can involve a group comprising national and international 'experts', sometimes using consultation mechanisms (open or limited).

This paper takes a practical approach, both in relation to asking 'what is the public good' but particularly in terms of asking 'who and/or what defines it' - a question which seems to be discussed less often in the literature. There are four main parts. Part I takes a broad look at the literature and how it distinguishes between the public good and private good. Education in general has traditionally been regarded as being for the public good. This view has also been extended to higher education because its benefits (graduates and public rates of return) extend beyond the individual to society, but there are also clear private benefits to the individual. Part II 
charts the increasing tension between the state and regulation, which appears in terms of friction between university autonomy and public accountability, and discussions around the 'social contract'. Part III looks at the growing usage of national strategies, performance compacts and performance pay in response to these tensions. Tensions around accreditation and the role of stakeholders in university governance reflect contestation around areas which have traditionally been firmly under the purview of the academy. It looks specifically at how this manifests itself in Ireland and the Netherlands, but also references growing tensions around accreditation in the US and teaching performance in the UK. Finally, Part IV reflects on the discussion thus far, and asks how tensions around public good objectives are being resolved, and considers whether we are witnessing a reframing of the process for determining the public good, with possible wider implications.

\section{Negotiating the public good}

The concept of public good has a long lineage. Confucius spoke of the 'public realm' as being 'dependent on the construction of a common world of meaning' which could only be 'upheld through reliance on the steady presence of private integrity' (Grange, 1996, 354). Both Plato and Aristotle emphasised the importance of ethics, metaphysics and natural philosophy as the means of educating citizens who would become 'good and harmonious member[s] of society' (Pedersen quoted in Moynihan, 2016, 13). Centuries later, the founding fathers of the contemporary university, John Henry Newman and Wilhelm von Humboldt, effectively assumed that, in so far as its establishment and purpose was aligned with the social reproduction of elites, the university served the public good (Green, 1997, 57); in the case of the former, this 'good' was explicitly Catholic, while for the latter it was Prussian - rather than a disembodied, cosmopolitan good. John Stuart Mill stated that something was a public good provided it benefited the community as a whole, or couldn't/shouldn't be provided privately, e.g. national defence. John Dewey took a slightly broader view, arguing that 'being an individually distinctive member of a community' constituted a public good, thereby placing the onus on the society 'to protect such spheres of creativity in its own self-interest' (quoted in Grange, 1996, 356).

In the 1950s, Paul Samuelson moved the discussion from 'the good' in the abstract or general, to the economic concept of goods in the particular. He sought to disentangle the inherent tensions between 'democratic politics (public rights) and capitalist markets (private rights)' (Labaree, 1997, 41) when he proposed the concept of a 'collective consumption good' (what subsequent economists refer to as a pure public good). Broadly defined, a private action is one which affects only those engaged in it, while a public action has consequences for others not directly concerned. Correspondingly, public and private goods are divided between state and non-state functions or responsibilities; as such public goods exist in the context of 'market failures', with the state stepping in to provide what private interests cannot. 
The conditions set by Samuelson for a public good are that it should be nonexcludable and non-rivalrous, with the standard examples being things such as sanitation, national defence and lighthouses (Heilbroner and Thurow, 1998, 155).

The question as to whether higher education is itself a public good or produces/contributes to 'public benefit' or 'public value' exposes fundamental tensions at the heart of this debate. Higher education has long been discussed in terms of being a public good or for the public benefit, and the history of this discussion and its implications is broad and varied.

Indeed, different and changing definitions of what is meant by 'public', or 'good', or 'benefit' show this to be a complex and fraught nexus of ideas and concepts (see Marginson 2011, 2016a and 2016b for a detailed examination and development of just these issues). The conditions of non-rivalry and non-excludability are central to the economic definition of a public good as proposed by Paul Samuelson. Though higher education is often discussed as 'a public good', in this strictest sense, the fact that access and participation rates are discussed as problems to be addressed suggest higher education is excludable and rivalrous. As Usher (2015) points out: 'Classroom space is very definitely rival[arous], and it is trivially easy to exclude people from education - no money, no degree.' In contrast, university-based research, which produces new knowledge, has been seen as closer to being a pure public good; its benefits are indivisible, and can be used by any number of people without being depleted (Stiglitz, 1999). In this sense, knowledge is not synonymous with either research as a process or the specific university as the site of research. However, it could be argued that academic pursuit of reputation, including the high prices charged by some academic publishers, exposes the fallacy that the scientific community is necessarily 'open' and its 'public goods...easily accessed' (King, 2011, 426). Academic peer review acts as a powerful gatekeeper apportioning access to 'positional goods' in an increasingly competitive environment (Hirsch, 1997, 6). As one way of addressing this, 'most funding agencies now require publicly funded research to publicise and communicate results in open-source formats' (Hazelkorn in Goddard et al., 2016).

That said, because of the 'social benefit efficiency gains and potential equity effects on opportunity and reduced inequality' (McMahon, 2009, 55), higher education is usually seen as serving the public good, especially when funded directly by the state. As such, McMahon $(2009,49)$ distinguishes between the public good in general and 'social benefits'. Brown $(2011,9)$ also acknowledges that while higher education may not meet the conditions for being a public good, it 'may still be undersupplied because it provides wider benefits, the costs of which cannot necessarily be recouped by the provider and reflected in the price set for the product'. The OECD notes both public and private benefits of higher education: 
Private rates of return: 'Individuals completing tertiary education benefit from substantial returns on investment: they are more likely to be employed and earn more than individuals without tertiary education do.' (OECD, 2014a, 150).

Public rates of return: '...investments in education generate public returns as tertiary-educated individuals pay higher income taxes and social insurance payments and require fewer social transfers.... In Austria, Belgium, Denmark, Germany, Hungary, Ireland, Italy, the Netherlands, Slovenia and the United States, tertiary-educated individuals pay considerably more in taxes and social contributions. In all these countries, earning premiums are above the OECD average and thus levies for social contribution are also higher.' (OECD, 2014a, 155-156).

The 'private good' view of higher education reached its most explicit formulation with the 2001 General Agreement on Trades and Services (GATS) which recognised higher education as a publicly traded service, thereby transforming it from a public good into a 'commodity' (Robertson, 2006).

Critics argue that a difficulty with these arguments is that the concept of public good is too strongly situated within the realm of economic 'utilitarianism' in contrast to its traditional and 'cultural' lineage which emphasised education's broader and intrinsic societal contribution (Bleiklie, 1998; see also Morgan and White, 2014; Bear and Mathur, 2015, 20; Rammell, 2016). Slaughter and Leslie (1997) notably argue that emphasis on higher education's economic or 'techno-science' role has pushed it closer to corporate values and profit-making in contravention of its assumed public good role. Pusser $(2006,19)$ draws on Habermas to argue the university is the public sphere', the place where 'open conversation and collaboration in a public space, where critiques could be generated in pursuit of the public good.' Delanty $(2001,9)$ likewise argues that 'the central task of the university in the twenty-first century is to become a key actor in the public sphere and thereby enhance the democratisation of knowledge'. According to Bergan et al. (2013), there is an intrinsic connection between democratic society and higher education through its commitment to the common good. This role is often asserted by seguing into higher education's contribution as 'anchors of stability and growth in their regions' (AAA\&S, 2016). Differing perspectives on the purpose, role and attributes of higher education reflect these myriad interpretations (Kerr, 2001; Duderstadt, 2000; CERI, 2009; Florida, 2012, 309-312).

Discussion about public good often takes place in the context of asserting philosophical and ideological views. Bleiklie $(1998,300)$, however, suggests that 'even without conscious attempts at changing the universities as organization, the sheer magnitude of their tasks would lead to sweeping changes in the ways they solve them.' According to Holley $(2006,205)$, how the different and competing sets of roles and interests are balanced inevitably moves consideration of public good beyond focusing on values and ties it directly to matters of governance. Pusser 
$(2006,16)$ identifies the early 1970 s in the US as the time when the 'public policy and institutional debates no longer turned on the question, 'Is the right to a higher education a public good?'... [but rather] Who Pays? Who Benefits? Who Should Pay?' For Tierney, this necessarily involves consideration of 'how things get done and whether the 'public' provides those services in ways different from those in the private sector' (Tierney, 2006, 2). Calhoun $(2006,10)$ similarly argues that such a discussion moves us beyond asserting that 'universities... have public missions' to 'ask[ing] about four senses of 'public': (1) where does the money come from? (2) who governs? (3) who benefits? and (4) how is knowledge produced and circulated?' Taking this as a starting point, the key issue in this paper is not whether, or not, education is a public good or contributes to public benefit, but rather how the public good is being addressed, and what the implications are for the university and society. As such, this paper does not consider matters of normative definitional questions, but rather assumes 'the public benefit' and 'the public good' are descriptively valid in the widest sense, and points to this notion's place in political and public discussion.

\section{Re-defining and re-regulating the 'social contract' and governance}

The earliest European universities focused predominantly on teaching the professions and elites, and owed their origin 'less closely to economic or demographic patterns than to the exercise of local political authority by the church or state' (Vallance in Goddard et al., 2016). The emergence of modern science in the Enlightenment era engendered a closer connection between the university and society, and underpinned the formation of the nation-state. During the early colonial days in the US, colleges were created with an emphasis on religion, which broadened to include democracy. Latterly, the establishment of civic universities in England and land grant universities in the US fit within this extended public good tradition, with comparable examples in other parts of the world. There was strong focus on community and democratic society, and higher education's responsibility to produce practical research of relevance to communities. As the systems expanded, newer types of institutions, such as vocational schools and colleges, polytechnics and community colleges, were established (Trow 1974, 124; Hazelkorn 2012a). In these instances, the state was the primary driver of change, creating educational institutions to meet a growing and widening social and economic agenda. Arguably the civic tradition was strongest in its earlier years. Growing differentiation and stratification between academic and professional education, between researchfocused and teaching-focused, and more recently by the growing influence of marketisation in higher education, have led to the 'civic disengagement of the academy' (Vallance in Goddard et al., 2016). Globalisation and the pursuit of 'worldclassness' have pitted pursuit of global reputation against local/regional commitment. ${ }^{4}$ 
Recent decades have seen changes in the relationship between the state and higher education, as it has between the state and other public services. Dill $(1998,362)$ describes a 'shift from an earlier uneasy balance between professional and state control to some new combination of state and market control'. Concepts such as 'managerialism' 'corporatisation' and 'marketisation' explain and describe a process of profound reform and restructuring across public services, with implications for the management and organisation of higher education, and academic culture and work. Ferlie et al. $(2008,326)$ argue that the types of 'steering patterns [being used] can be linked to underlying narratives of public management reform which apply to higher education subsystems as well to other public service subsystems', albeit their precise form is context- and path-dependent. At the same time, there was increasing interest in the role of the market as a more effective means by which to drive change, efficiency and public benefit for customers and consumers (van Vught, $2007,15)$. Neave suggests the emergence of the 'evaluative state' is part of a longer-term re-balancing between higher education and the state, one that is 'embedded' in the massification of higher education and the desire to ensure 'more rapid responses from institutions of higher education' (1998, 282; see also DahlerLarsen, 2007, 615). The origins of these changes across the UK, Australia and the US in the 1970s-1980s are often associated with the political rise of neoliberalism in those countries, and tied with the fiscal crisis of the state (O'Connor, 1973), with consequent spill-over effects internationally (Kaiser et al., 1994).

Others, such as Guston (2000; Guston and Kenniston, 1994), have situated the origin of change in debates between scientists and the US federal government towards the end of WW2, and the realisation that scientific knowledge could be a competitive advantage. The shift was marked initially by publication of Science, The Endless Frontier which closely aligned social and economic progress with the belief that 'new products, new industries, and more jobs require continuous additions to knowledge of the laws of nature, and the application of that knowledge to practical purposes' (Bush, 1945). Science would be privileged - in other words, publicly funded - as long as there were expectations of usefulness. This 'golden age', in which 'money flowed freely' and government did not 'interfere' with a self-regulating scientific community, was predicated upon a social contract in which both sides upheld (often unstated) parts of the bargain. By the 1970s, however, the public began to express concerns, inter alia, about research's costliness and value (Guston, 2000, 115). Greater public scrutiny followed.

These deliberations took on greater potency as the knowledge economy paradigm, globalisation, and (more recently) the depth and longevity of the Great Recession harnessed higher education's fortunes directly to that of the nation-state, and vice versa. Ambitions to strengthen competitiveness and secure a greater share of the global market, to ensure appropriate capacity and capability across the innovation system, and to reinforce the impact on and benefit for the economy and society placed higher education at the centre of policymaking. This transformed the university from a locally-based institution to one with geopolitical significance (Douglass, 2010, 24). Since 2003, global rankings have played their part in 
highlighting, comparing and measuring success in terms of global science (Hazelkorn, 2015; 2016). But, because higher education and its outputs do not exist in isolation, issues of performance and productivity, quality and excellence, and outcomes and impact have become part of an increasingly politicised and public conversation around the world. There have been resulting implications for governance, management and organisation, for funding and resources, and for the language and actions around dissemination - now expressed in terms of demonstrating, showcasing and assessing outcomes, impact and benefits.

Institutional autonomy accompanied by academic peer review have both been prized principles of the academy, underpinning academic-professional self-regulation (Rowland, 2002, 248). University autonomy has been an important symbol of independence of thought and decision-making, enabling the academy to shape its curriculum and research, be the primary determinant of quality, and speak 'truth to power', even in politically challenging environments. University autonomy was affirmed in the Bologna Declaration with reference to the Magna Charta Universitatum (1988); ${ }^{5}$ it had been a long-standing principle of US higher education with roots in the first amendment of the constitution. Pusser $(2006,21)$ notes that the 'public sphere depends on autonomy at many levels - individual, institutional, and social - to enable unfettered critical engagement to flourish.' But, arguably and ironically, the attributes which have underpinned autonomy's value to the academic community are precisely those which are contributing to a breakdown in trust between higher education and students, policymakers and civil society, undermining the social contract (Harman, 2011; Hazelkorn and Gibson, 2016). There has been a growing distrust with traditional collegial mechanisms, and what appear to be labyrinthine and obscure processes, and weak articulation of the rationale for public expenditure in pursuit of public goods (Austin and Jones, 2016, 81). Over the years, there have been various trade-offs and accommodations between accountability and autonomy, but too often genuine public interest has been brushed aside as the rhetoric of neoliberalism. Ultimately 'society has a right to know whether its institutions are capable of meeting its expectations' (Massaro, 2010, 22). If higher education is the engine of the economy - as the academy has regularly argued (Castells, 1994; Baker, 2014; Lane and Johnstone, 2012; Taylor, 2016) - then its productivity, quality and status is a vital - and valid - indicator of sustainability and competitiveness.

Early on, Trow $(1974,91)$ acknowledged that as the system expands, and matters of higher education come 'to the attention of larger numbers of people, both in government and in the general public...[they will] have other, often quite legitimate, ideas about where public funds should be spent, and, if given to higher education, how they should be spent'. As higher education expands in terms of students and providers, new modes of achieving accountability are required and gain prominence. Clark's (1983) classic 'triangle of coordination' (between the state, markets and the academy) has been overtaken as the number of societal actors has increased. Nowadays, it's more attuned to a 'pentagon', in recognition of the role played by students, often described as partners or customers, employers, and society more 
broadly, often described as stakeholders in the innovation eco-system. This corresponds with the transformation from the 'triple helix' into 'quadruple helix' and then the 'quintuple helix' (Etzkowitz and Leydesdorff, 1997; Europa, 2005; Carayannis, 2012a, 2012b), and moves accountability beyond both Mode 1 peer review/self-accountability and Mode 2 peer review and societal accountability (Gibbons et al., 1994;).

Thus, Mode 3 knowledge acquires accountability via actively-engaged societal intervention, public endorsement and principles of reciprocity, encouraging and incorporating processes and dynamics that allow for both top-down government, university, and industry policies and practices and bottom-up civil society and grassroots movements initiatives and priorities to interact and engage with each other towards a more intelligent, effective, and efficient synthesis (Hazelkorn, 2012, 843; Hazelkorn in Goddard, 2016, 40-44; see also Carayannis and Campbell, 2012, 3 ). The emphasis on multi-actor environments challenges traditional views of the university as the sole benefactor of knowledge, and forces it to actively engage with societal, civil and economic stakeholders, and connect with issues, problems and organisations beyond its campus boundaries (Goddard et al., 2016; OECD, 2006, 124). The EU has begun to push greater public involvement in science through adoption of its Responsible Research and Innovation (RRI) and open science strategies (Europa, n.d.). ${ }^{6}$

Massification has altered underlying assumptions of the university's and the academy's commitment to the public good, or at the very least brought them into question. Articulating the responsibility of the university to society is not new, but it has been given greater saliency as the student cohort has diversified and the challenges facing society have heightened in intensity (Barnett, 2000, 23). The European University Association acknowledged that the current debate around 'institutional autonomy' reflects the

constantly changing relations between the state and higher education institutions and the degree of control exerted by the state....in response to the demands of society and the changing understanding of public responsibility for higher education. (Estermann and Nokkala, 2009, 6)

Almost regardless of world region, the content of the discourse is readily familiar. There has been a noticeable shift to measuring teaching and learning outcomes to allow the public to judge whether graduates have the threshold qualities expected. Universities, and individual scholars, are asked to demonstrate their contribution or the impact or value of publicly-funded research - with the operative word being 'demonstrate'. No matter how much these discussions vary, it's clear that determining quality no longer rests solely with the academy, higher education providers or (even) quality assurance agencies or accreditors (Harman, 2011, 51; Dill and Beerkens, 2010, 313-315; Hazelkorn, 2012). There is also a growing desire to move beyond assessing quality to linking quality to relevance and resources (OECD, 2010). Rankings purport to speak to this policy and political agenda, not 
least because they are perceived as an independent interlocutor between higher education and society. But, while they gain considerable media and political attention, their narrow focus on elite universities and research is their Achilles heel. They can't adequately serve government nor respond to the 'public good' agenda.

\section{System steering: Ireland and the Netherlands}

During the 1990s, there was a shift towards market-led and competitive mechanisms as the preferred way to regulate higher education, with government adopting a 'steering-from-a-distance' approach. In more recent years, acknowledging the role higher education plays within the national eco-system, there has been a noticeable move in favour of greater co-ordination. These changes reflect wider discussion around the limits to the role of the market in many other domains, such as banking and financial services. In response, governments have stepped up their role, endeavouring to steer, (re)regulate and (re)structure higher education in ways which, while supportive of autonomy, use various mechanisms to ensure a closer alignment between higher education and national objectives. The EU announced its Modernisation Agenda in 2006 (Europa, 2006, 2007;) (a revised agenda is under consideration) with emphasis on quality, transparency and comparability (Hazelkorn, $2012 b)^{7}$ following the US Commission on the Future of Higher Education (2005) report that had earlier proposed new accountability measures based on 'better data about real performance and lifelong working and learning ability' (CFHE, 2006, 14). Despite opposition, the Obama government's Education Scorecard eventually emerged in 2015. More recently, accreditation has been subjected to what is seen as 'inappropriate intervention' (Broad, 2010), becoming not just a topic during the US presidential primaries, but the topic of proposed new legislation and inquiries by the Government Auditing Office (GAO) (Camera, 2016; Eaton, 2011; Warren, 2016; GAO, n.d.). Similar developments surround the UK government's proposals to restructure the architecture of HE governance, and the Teaching Excellence Framework (TEF) (BIS, 2016; Middlehurst, 2016).

Van Vught has described 'efforts of government to steer the decisions and actions of specific societal actors according to the objectives the government has set and by using instruments the government has at its disposal' (1989, 21; see also Europa, 2014). Many countries have introduced performance-based funding models to encourage or 'nudge' (Thaler and Sunstein, 2006) universities to focus on specific outcomes in line with government priorities. This has also been a strong feature of many US state systems (Dougherty and Reddy, 2011; Miao, 2012). Ontario, Canada has introduced a system of strategic mandate agreements to shift discussion away from 'how much money is spent on higher education' to 'how the money is spent and what outcomes are being achieved' (Weingarten et al., 2015; Hicks, 2015; HECQO, 2013). The UK research assessment exercise/research excellence framework (RAE/REF) are similar examples. Rather than more traditional approaches which rely on annual base-line or core funding based on input factors, historic calculations, 
political decision and/or lobbying, performance-based funding rewards organisations based on expected or actual performance (Ziskin et al., 2014). An alternative approach, gaining considerable traction internationally, is performance agreements variously called compacts or contracts, which resonate with the social contract model discussed above. This approach also looks at future performance, but rather than the simple top-down formula mechanism, the latter relies on a diplomatic process which recognises and respects institutional autonomy and usually involves a discussion or 'negotiation' between the funder (the ministry or its agency) and the institution around a set of objectives and performance targets (de Boer et al., 2015; Benneworth et al., 2011). The government agrees with the expected planned performance, and an agreement is signed. ${ }^{8}$ Some examples of countries which fit within these models are in Table 1 below.

Table 1 Performance-based Funding and Performance Agreements

\begin{tabular}{|l|l|}
\hline $\begin{array}{l}\text { Performance-based Funding and } \\
\text { Performance Agreements }\end{array}$ & Reference Jurisdictions \\
\hline Performance-based Funding & Israel, Northern Ireland \\
\hline Performance Agreements & $\begin{array}{l}\text { Australia, Finland, Hong Kong, } \\
\text { Ireland, Scotland, Ontario, New } \\
\text { Zealand, }\end{array}$ \\
\hline Input or Annual Funding & England, Alberta, Wales \\
\hline
\end{tabular}

Source: Hazelkorn, 2016, 46

The following two vignettes describe how two different European countries are effectively reconfiguring the 'social contract' between higher education and the state. The last section will look at some of the issues that arise in the process.

\section{Ireland}

Between the late 1950s and the millennium, Ireland was transformed from relative isolation, self-imposed protectionism and late industrialisation to becoming an important English-speaking 'digital isle', a beach-head between the US and Europe. For a country with few natural resources, Ireland's membership of the European Economic Community (later the European Union) and the OECD, and subsequent adoption of the knowledge economy paradigm, were pivotal to framing policies for economic growth (Forfás, 1995). As a small open economy, part of the EU but on the edge of Europe, global competitiveness and then the global financial crisis exposed structural problems of over-dependence on multinational corporations, a narrow tax base and high dependence on debt-based consumption, leaving the country with high levels of both public and private debt. In response, a series of key policy documents and national strategies placed higher education and university-based research at the centre of the policy mix. Building Ireland's Smart Economy (DoT, 2008) endorsed heavy investment in R\&D and promoted reform and restructuring of 
higher education, with 'new organisational mergers and alliances that can advance performance through more effective concentration of expertise and investment'; the Report by the Innovation Taskforce (2010) reinforced this vision (Hazelkorn and Massaro, 2011).

In parallel, the state began to take a keener interest in the overall shape of the higher education landscape, the outcomes, management and governance of higher education (Hazelkorn, 2014; Hazelkorn et al., 2015, Hazelkorn and Gibson 2016). The National Strategy for Higher Education to 2030 set out a 'comprehensive policy and operational framework for the development of our higher education system' (DES, 2011, 2). The concept of the system-as-a-whole was introduced as a counterweight to the view promulgated by university rankings - which elevates the performance of individual institutions - not least because the country's size and budget arguably prohibited an alternative strategy.

Consequently, the report endorsed the idea of a confederation of autonomous HEls working together for mutual benefit to aid regional development and global competitiveness. Institutional compacts, 'negotiated' through a process called 'Strategic Dialogue', have been designed to better align institutional mission and performance with overall national policy objectives (HEA, 2013). The latter have been set down by the government in the Higher Education System Performance Framework, 2014-2016 (currently being revised for 2016-2019) (DES, 2014, 1). Underpinning these developments has been a greater focus on informationgathering, as a means of strategically understanding the system but also as a means for comparison and broader accountability; this includes a tool-kit to profile HEI performance according to a wide range of indicators, which corresponds with initiatives that the European Union has also undertaken (HEA, 2015; U-Map, n.d.).

At the same time, research management and funding at a national level was restructured, with down-stream implications for institutional organisation and management of research. The Research Prioritisation Exercise (RPE) favoured a 'more top-down, targeted approach' for 14 priority areas strongly aligned to industrial sectors (Forfás, 2011). Explicit reference to economic relevance trumped broadbased excellence, and the role of science and technology effectively side-lined historic affiliations to the arts and humanities (Gibson and Hazelkorn, forthcoming; Benneworth et al., 2016). Innovation 2020 (ICSTI, 2015) introduced as Ireland began to emerge from recession, was more positive, moving away from the shriller language of research prioritisation. Nonetheless, the bigger picture remains.

\section{Netherlands}

The Dutch government over time has assumed a greater role in the affairs of higher education institutions in the Netherlands, starting with the University Reform Act of the 1970s. This was in part a reaction to the international student unrest of the 1960s, and saw efforts to 'democratise' the governance of the university. This led to 
bureaucratisation through increased rule-making, as greater involvement of other stakeholders (such as students) with regulations took the place of corporate traditions as the basis of university governance. The other factor influencing changes in Dutch higher education was a period of prolonged economic downturn, and legislation in 1975 continued the trend of government involvement, with the intention to make universities more productive and efficient, and introducing the principle of long-range scientific planning (Geiger, 1986, 94-96). This was an attempt by the government to 'bring science and technology back under economic control' as a response to continued decline in the Dutch economy (Benneworth et al., 2016, 130132). This introduced programmatic research funding for the first time, in the areas of energy, environment, labour market and demography. The most recent, and profound, set of reforms started in 2011 with the Veerman Commission on the Future Sustainability of the Dutch Higher Education System, and the subsequent white paper (MoECS, 2011). This set out the rationale for the government's blueprint for reform, noting that drop-out rates were high, and that the system wasn't meeting the varied needs of students and labour markets.

This report met with broad support across various stakeholders (HEls, students, employer organisations, parliament, and government), and a process of collective and individual performance agreements was proposed to address education quality, student progression rates, as well as 'valorisation' of research. Universities and Universities of Applied Sciences (UaS) both signed collective strategic agreements with the relevant government ministries through their associations, which provided a framework for the agreements made by individual HEls that followed (OECD, 2014). Another policy response sought greater differentiation of the HE system, in terms of system structure, institutional profiles, and programmes. In 2015, the Dutch Ministry of Education, Culture and Science published The Value of Knowledge - Strategic Agenda for Higher Education and Research 2015-2025 (MoECS, 2015a). This noted the findings and reforms implemented by the Veerman Commission, specifically the implementation of the performance agreements across the higher education sector (see also MoECS, 2011). The agenda sets out ambitions under the headings: worldclass education; accessibility, talent development, and diversity; and social relevance.

Formulation of the Dutch National Research Agenda involved a coalition of the universities, universities of applied sciences, university medical centres, various national research organisations and academies, and the Confederation of Netherlands Industry and Employers. This coalition sought to identify questions that form the foundation for research areas, and could be societal challenges or economic ones. Critically, the process was opened to the public via an online platform, whereby anybody in the Netherlands could submit questions to research. The resulting 11,700 questions were assessed for usefulness for the national research agenda, and ultimately 140 scientific questions were identified through this crowd-sourcing process (MoECS, 2015b). 
These national examples illustrate the changing nature of how higher education serves the public good, and how public benefit is conceived. More generally, in structural terms they illustrate that the factors leading to these shifts can be social, political, as well as economic. The factors influencing these changes can be at the level of an entire society, which lends legitimacy to the process whereby a variety of stakeholders call for and support reform in a system. As such, changes in the conceptualisation of public benefit are not simply a one-way matter of elites forcing change on the academy. More specifically, the Dutch examples illustrate how the national 'politics of accommodation' (Lijphardt, 1975) influences this process of balancing the needs of various sectors in society, the academy, and the economy to come to some agreement on the role of higher education. In addition, while public consultation exists elsewhere (see, for example, New Zealand Productivity Commission (2016)), the Dutch National Research Agenda online platform shows how the public is being brought into this process in a very systematic and direct way rather than using a representative format. The example of Ireland illustrates that the 'public benefit' can be understood as plural, and that HEls can (be nudged to) come together to define goals that meet their institutional needs while also serving this public benefit. This may be reflective of the Irish and Dutch political systems and cultures as consensual democracies (Lijphardt, 2012). In contrast to the US and the UK majoritarian political cultures, both the Dutch and Irish have proportional representation systems whereby coalition government is the rule rather than the exception. This necessitates a less directly adversarial manner of doing business than is the case in the UK and the US. As such, the politics of deciding the public benefit in terms of what the state should fund and to what extent has a somewhat more cooperative nature, and zero-sum arguments are less common. This may also militate against the notion of a 'neoliberal' elite imposing change against the will of the clear majority of people, in these countries at least.

\section{Re-framing the public good}

The economic and political environment over recent years has transformed the policy imperatives around higher education and research, as well as all other public services. There are heightened concerns about value for money and return on (public) investment almost everywhere, albeit to different degrees, which have led to greater government direction of the higher education and research systems. There is less public tolerance of academic privilege and self-promotion; almost everywhere there has been a decline in public trust (Enders, 2013). Whereas universities once 'had a sense of shared intellectual purpose (at least to a degree), bolstered by the security of centralised funding and control', their environment for some time has been 'more complex, fluid and varied' (Meek, 2003, 4). There is a growing and wider range of different interests to which higher education must respond. This shift is often portrayed in terms of the ascent of neoliberalism and a betrayal of university interests. In contrast, this paper seeks to reframe the debate in terms of managing the public good; as Brewer suggests, '( $m$ )arketization may have provoked interest in 
redefining our public value' but there is a necessity and urgency to engage directly with the issues and to 'shift the terms of the debate away from public impact...to public value' $(2013,12)$.

In looking at the cases of Ireland and the Netherlands, there is evidence that the state-university interface is undergoing a re-configuration. The importance of responding to labour market needs is not simply acquiescing to the market, but responding to the needs of students for employment. In the wake of prolonged recession and slow recovery, there is an expectation that higher education, given its importance to society and the economy, and to individuals, has a responsibility to help meet these needs - and by asserting this role, there is a presumption that this is not being done or perhaps not being done sufficiently. Different governments describe their efforts as creating the appropriate 'architecture' for steering the system, governing the system, and holding the system to account, according to the governmental programme and common goals. Historical, social, cultural and economic contexts play a big role in framing the context. For example, under the 'Nordic model', higher education was perceived as a public good, and the state was seen as a protector of these values. More recently, as an exchange relationship has emerged, there has been a shift from steering by trust, to steering by more technocracy and control. While some countries tie money to the process, not all do albeit that is likely to follow. Tensions can arise if/when (some) 'universities are not willing to or able to, or they don't see that as a good solution to do structural reforms (...) and that affects the whole system' (HEA, 2016). The strategic dialogue process and performance agreements are viewed as important means to reconstruct trust as well as to meet the requirements of the public accountability agenda in a way that acknowledges, supports and balances autonomy with national objectives.

Dee $(2006,134)$ argues that 'governance systems advance the public good when institutions are engaged in a system of mutual obligation with the communities in which they are embedded.' Some HE system leaders offer a similar rationale for explaining not only engagement with the institutions but with the various publics, the latter being a mechanism for including the diversity of opinion and effectively circumnavigating difficulties which have traditionally beset 'town' and 'gown' relations. It is not self-evident that 'acting in the interest of the campus becomes synonymous with acting in the interest of the community', but it does open the potential that it can 'inoculate themselves against future external intrusions that diminish autonomy' (Dee, 2006, 134, 140). Reflecting the comments of government above, Dill $(2001,29)$ similarly argues that the new policy environment requires greater regulation. The new accountability mechanisms vary across a spectrum from (de/re)regulation to public accountability, with the latter involving aspects of information provision, capacity building, and performance funding.

Analyses often posit a one-dimensional conceptualisation of neoliberalism or new public management (NPM), describing governance in terms of the adoption of private corporate mechanisms to public sector organisations and not just higher education (King, 2009, 42). It is operationalised in terms of control and power, and 
often refers to matters of resource allocation (Morrell, 2009). In this context, understandably, there is resistance - a worry that what is unique about the academy is being imperilled. A contrary view suggests that reconfiguring the public good as a set of negotiations enables opportunities for higher education to both defend and expand its sectoral and institutional demands. The process of performance agreements or compacts shows that different goals need not be mutually exclusive, and being responsive to society can give the academy's own goals legitimacy in a wider sense.

Similarly, the greater importance of transparency in politics, and the role of technology and the internet in facilitating public interest and involvement, suggests that further change is likely. Consideration of the relevance to higher education provides dialogue in ways which enable the public to be involved directly in defining and participating in decisions relating to the public good, rather than having the decisions made for them. Previously, the relationship between the university and the public had been one-way 'engagement', communicating the university's work to the public (which conveniently also served as a form of positive public relations for higher education). This was an essentially one-way vector in the 'public communication of science', in which the universities tried to get the public to 'understand' the university and its work (Pickstone, 1999, 27). The limitations of this approach saw a move towards understanding of science for the public (Pickstone, 2000). Arguably, we are entering a new phase with new platforms and crowdsourcing, with understanding of science by the public (Adshead and McInerney, n.d.). Indeed, as elevated an institution as NASA now canvasses the public for ideas of small scientific payloads that could be brought to the moon (Grush, 2016; FBO, 2016). New technologies make the participation of citizens in deliberative processes easier than ever, and the academy has an opportunity now to deepen the public's engagement with education and research, and to redefine the public good through open discussion with the public (Hazelkorn et al., 2005, 24-25). There is no doubt that this 'brave new world' will be problematic; there are considerable gaps in understanding. But it may be the only way forward if higher education wants to avoid creeping interventionism. 


\section{Bibliography}

AAUP (1940) 'Statement of Principles on Academic Freedom and Tenure', Washington, DC: American Association of University Professors, Accessed 4 November 2016, from https://www.aaup.org/file/1940\%20Statement.pdf

Adshead, M. and McInerney, C. (n.d.). "By the People, for the People'. Bringing public participation back to politics,' University of Limerick. Retrieved 27 February 2017, from http://www.ul.ie/research/sites/default/files/Case-4-politics.pdf

American Academy of Arts and Sciences. (2016). Public Research Universities: Serving the Public Good. Cambridge, Massachusetts.

Austin, I. and Jones, G.A. (2016) Governance of Higher Education. Global Perspectives, Theories and Practices. New York and London: Routledge.

Baker, D. P. (2014). The Schooled Society: The Educational Transformation of Global Culture. Stanford, CA: Stanford University Press.

Barnett, R. (2000). Realizing the University in an Age of Supercomplexity. Buckingham: SRHE and Open University Press.

Bear, L., and Mathur, N. (2015). Introduction: Remaking the Public Good: A New Anthropology of Bureaucracy. The Cambridge Journal of Anthropology, 33(1), 1834. http://doi.org/10.3167/ca.2015.330103

Benneworth, P., de Boer, H., Cremonini, L., Jongbloed, B., Leisyte, L., Vossensteyn, $\mathrm{H}$. and de Weert, E. (2011) Quality-related funding, performance agreements and profiling in higher education. Enschede, Netherlands: Centre for Higher Education Policy Studies (CHEPS), Universiteit Twente.

Benneworth, P., Hazelkorn, E. and Gulbrandsen, M. (2016) The Impact and Future of Arts and Humanities Research. Basingstoke: Palgrave Macmillan.

Bergan, Sjur, Ira Harkavy and Hilligje van't Land (eds) (2013), Reimagining Democratic Societies: A New Era of Personal and Social Responsibility, Higher Education Series, No. 18, Strasberg: Council of Europe.

BIS (2016) Success as a knowledge economy: teaching excellence, social mobility and student choice. London: Department for business, Innovation and Skills; Middlehurst, R. (2016) 'UK Teaching Quality Under the Microscope: What are the Drivers?', International Higher Education, No. 84, Winter, 27-29.

Bleiklie, I. (1998) 'Justifying the evaluative state. New public management ideals in higher education,' European Journal of Education, 33(3), 299-316 
Boyer, Ernest L. (1996), 'The Scholarship of Engagement', Journal of Public Service and Outreach, 1 (1), 11-20.

Brewer, J. D. (2013) The Public Value of the Social Sciences: An Interpretive Essay, London: Bloomsbury Academic.

British Social Attitudes (2013) 'Higher Education. Investing in the future? Attitudes to University', London: NatCen Social Research. Accessed 4 November 2016, from http://www.bsa.natcen.ac.uk/media/38917/bsa32 highereducation.pdf

Broad, M. (2010) 'Academic Freedom and Institutional Autonomy in the United States: Balancing Rights and Responsibilities', Council of Europe, Strasbourg. Washington, D.C.: American Council of Education.

Brown, R. (2011). 'The Impact of Markets'. In Brown, R. (2011) 'The Impact of Markets'. In R. Brown (Ed.), Higher Education and the Market. Abingdon and New York: Routledge, 20-52.

Bush, V. (1945) Science, The Endless Frontier. Washington, D.C.: Office of Scientific Research and Development, https://www.nsf.gov/od/lpa/nsf50/vbush1945.htm

Calhoun, C. (2006). The University and the Public Good. Thesis Eleven, 84(1), 7-43.

Camera, L. (2016, 22 September) 'Democrats Look to Increase Federal Role in College Accreditation, US News and World Report, Accessed 4 November 2016, from http://www.usnews.com/news/articles/2016-09-22/democrats-look-to-increasefederal-role-in-college-accreditation

Carayannis, Elias G. and David F.J. Campbell (2012). 'Mode 3 Knowledge Production in Quadruple Helix Innovation Systems. Twenty-first-Century Democracy, Innovation, and Entrepreneurship for Development', SpringerBriefs in Business, 7(64), 1-63.

Carayannis, Elias G., Thornsten D. Barth and David F.J. Campbell (2012). 'The Quintuple Helix innovation model: global warming as a challenge and driver for innovation', Journal of Innovation and Entrepreneurship, 1(2).

Castells, M. (1994) 'The University System: Engine of Development in the New World Economy.' In Salmi, J. and Vespoor, A. M. (Eds.) Revitalizing Higher Education, Pergamon, Oxford, 14-40.

CERI (2009) Higher Education to 2030, v. 2. Globalisation, OECD, Paris.

CFHE (2006) A Test of Leadership. Charting the Future of U.S. Higher Education, Commission on the Future of Higher Education, Report of the Commission appointed by Margaret Spellings, Secretary of Education, Department of Education, USA, 
Accessed 4 November 2016, from

http://www2.ed.gov/about/bdscomm/list/hiedfuture/reports/final-report.pdf

Clark, B. R. (1983) The Higher Education System: Academic Organization in CrossNational Perspectives. Berkeley, CA: University of California Press.

Dahler-Larsen, P. (2007). 'Evaluation and Public Management', In: E. Ferlie, L. E. Lynn Jr., and C. Pollitt (Eds.). The Oxford Handbook of Public Management. Oxford: Oxford University Press. doi:10.1093/oxfordhb/9780199226443.003.0027

De Boer, H., Jongbloed, B., Benneworth, P., Cremonini, L., Kolster, R., Kottmann, A., Lemmens-Krug, K., and Vossensteyn, H. (2015) Performance-based funding and performance agreements in fourteen higher education Systems. Report for the Dutch Ministry of Education, Culture and Science. Enschede, Netherlands: Centre for Higher Education Policy Studies (CHEPS), Universiteit Twente.

Dee, J. (2006) 'Institutional Autonomy and State-Level Accountability. Loosely Coupled Governance and the Public Good', In: Tierney, W. (Ed.) Governance and the Public Good. Albany, NY: State University of New York Press.

Delanty, G. (2001). 'The University in the Knowledge Society'. Organization, 8(2), 149-153.

DES (2011). National Strategy for Higher Education to 2030. Dublin: Department of Education and Skills. Accessed 4 November 2016, from http://www.hea.ie/sites/default/files/national_strategy for higher_education_2030.pd $\underline{f}$

DES (2014) Higher Education System Performance Framework, 2014-2016, Dublin: Department of Education and Skills. Accessed 4 November 2016, from https://www.education.ie/en/The-Education-System/Higher-Education/HEA-HigherEducation-System-performance-Framework-2014-2016.pdf

Dill, D. D. (2001) 'The regulation of public research universities: Changes in academic competition and implications for university autonomy and accountability', Higher Education Policy, 14(1), 21-35.

Dill, D. D., and Beerkens, M. (Eds.)(2010) Public Policy for Academic Quality. Analyses of Innovative Policy Instruments. Dordrecht: Springer.

Domonell, K. (2013, 6 February) 'Gallup/Lumina Foundation Poll Reveals Public Perception of Higher Ed', UB University Business. Accessed 4 November 2016, from https://www.universitybusiness.com/article/galluplumina-foundation-poll-revealspublic-perception-higher-ed 
DoT (2010) Building Ireland's Smart Economy. A Framework for Sustainable Economic Renewal. Dublin: Department of the Taoiseach.

http://www.taoiseach.gov.ie/BuildinglrelandsSmartEconomy 1 .pdf

Dougherty, K.J. and Reddy, V. (2011) The Impacts of State Performance Funding Systems on Higher Education Institutions: Research Literature Review and Policy Recommendations, CCRC Working Paper No. 37. New York: Community College Research Centre (CCRC), Columbia University

Douglass, J.A. (2010) Higher Education Budgets and the Global Recession: Tracking Varied National Responses and Their Consequences (CSHE 4.10). University of California Berkeley: Center for Studies in Higher Education.

Duderstadt, James J. (2000), A University for the $21^{\text {st }}$ Century, Ann Arbor: University of Michigan Press.

Eaton, J. S. (2011). U. S. Accreditation: Meeting the Challenges of Accountability and Student Achievement. Higher Education, 1(June): 1-20.

Enders, J. (2013). 'The university in the audit society: on accountability, trust and markets'. I Engwall L. and Scott, E. (Eds), Trust in Universities. London: Portland Press, 53-68.

Estermann, T. and Nokkala, T. (2009) University Autonomy in Europe 1. Brussels: European University Association. Accessed 4 November 2016, http://www.eua.be/policy-representation/governance-funding-and-publicpolicy/projects/university-autonomy-in-europe.aspx

Etzkowitz, H. and Leydesdorff, L. (1997) Universities and the Global Knowledge Economy: A Triple Helix of University-Industry-Government Relations. Andover, U.K.: Thomson Learning.

Eurobarometer (2009) Students and Higher Education Reform. Survey among students in higher education institutions, in the EU Member States, Croatia, Iceland, Norway and Turkey. Special Target Survey. Analytical Report. Brussels: DG

Education and Culture. Accessed 4 November 2016, from http://ec.europa.eu/public opinion/flash/fl 260 en.pdf

Europa (2005) 'Working together for growth and jobs: A new Start for the Lisbon Strategy', Communication from President Barroso in agreement with Vice-President Verheugen to the Spring European Council, COM (2005) 24 final.

Europa (2006) Delivering on the modernisation agenda for universities: Education, research and innovation. Communication to the Council and the European 
Parliament, (COM) 2006208 final.

http://www.madrimasd.org/proyectoseuropeos/documen-

tos/doc/education research and innovation.pdf

Europa (2007) Council resolution on modernizing universities for Europe's

competitiveness in a global knowledge economy (2007/CXXX/YY). Brussels: Council of the European Union.

www.consilium.europa.eu/ueDocs/newsWord/en/intm/97237.doc.

Europa (2010) Europe 2020: A European strategy for smart, sustainable and inclusive growth. Communication from the Commission. COM (2010) 2020. Brussels: Council of the European Union.

http://ec.europa.eu/eu2020/pdf/COMPLET\%20EN\%20BARROSO\%20\%20\%20007 \%20-\%20Europe $\% 202020 \% 20-\% 20$ EN\%20version.pdf

Europa (2014). Performance agreements and their relationship to funding in higher education. Brussels. Retrieved from http://ec.europa.eu/education/policy/strategicframework/expert-groups/documents/performance-agreements en.pdf

Europa (n.d.) Responsible Research and Innovation, https://ec.europa.eu/programmes/horizon2020/en/h2020-section/responsibleresearch-innovation

FBO - Federal Business Opportunities (2016) 'Small Lunar Surface Payload Request for Information (RFI)', Accessed 4 November, from https://www.fbo.gov/index?s=opportunity\&mode=form\&id=cbcd56e6afbd7dfad1ef9cd $\underline{0 \mathrm{fb} 52 \mathrm{~b} 6 \mathrm{f} 7 \& \mathrm{tab}=\mathrm{core} \& \mathrm{cview}=0}$

Ferlie, E., Musselin, C., and Andresani, G. (2008). 'The steering of higher education systems: a public management perspective', Higher Education, 56(3), 325-348.

Florida, R. (2012) The Rise of the Creative Class, Revisited. New York: Basic Books.

Forfas (1995) 'Executive Summary', Science, Technology and Innovation Advisory Council Report, Dublin: Forfás. Accessed 4 November 2016, from http://www.forfas.ie/media/forfas950327 science technology innovation.pdf

Forfás (2011) Report of the Research Prioritization Steering Group, Dublin: Forfás. GAO - Government Accountability Office (n.d.) 'Postsecondary Education Access and Affordability', Accessed 4 November 2016, from

http://www.gao.gov/key issues/postsecondary education_access affordability/issue summary\#t=0.

Geiger, R. (1986) Private Sectors in Higher Education. Ann Arbor, MI: The University of Michigan Press. 
Gibbons M, Limoges C, Nowotny H., Schwartzman, S., Scott, P. and Trow, M. (1994). The New Production of Knowledge: The Dynamics of Science and Research in Contemporary Societies. London: Sage.

Gibson, A. and Hazelkorn, E. (2016) 'Arts and humanities research, redefining public benefit, and research prioritization in Ireland', Manuscript submitted for publication.

Goddard, J., Hazelkorn, E., Kempton, L. and Vallance, P. (Eds) (2016). The Civic University: the policy and leadership challenges. Cheltenham: Edward Elgar.

Goodwin, M. L. (2016, 22 July) 'What Really Caused Brexit?', Newsweek, Accessed 4 November 2016, from http://europe.newsweek.com/Brexit-causes-result-whovoted-leave-eu-analysis-matthew-goodwin-483100?rm=eu

Grange, J. (2016). 'The Disappearance of the Public Good: Confucius, Dewey, Rorty', Philosophy East and West, 46(3), 351-366.

Green, A. (1997). Education, Globalization and the Nation State. Basingstoke: Palgrave Macmillan.

Grush, L. (2016, 2 November). 'NASA is crowdsourcing ideas to study the surface of the Moon', The Verge. Accessed 4 November, from

http://www.theverge.com/2016/11/1/13486118/nasa-instruments-request-forinformation-moon-surface

Guston, D.H. (2000). Between Politics and Science. Assuring the Integrity and Productivity of Research. New York and Cambridge: Cambridge University Press.

Guston, D.H. and Keniston, K. (1994). 'Introduction: The Social Contract for Science'. In Guston, D.H. and Keniston, K. (Eds.). The Fragile Contract. University Science and the Federal Government. Cambridge and London: MIT Press, 1-41

Harman, G. (2011). 'Competitors of Rankings: New Directions in Quality Assurance and Accountability.' In Shin, J. C., Toutkoushian, R. K. and Teichler, U. (Eds.) University Rankings. Theoretical Basis, Methodology and Impacts on Global Higher Education. Dordrecht: Springer, 35-54.

Hazelkorn E. and V. Massaro (2011). 'A Tale of Two Strategies for Higher Education and Economic Recovery: Ireland and Australia', Higher Education Management and Policy, 23:2, 1-24.

Hazelkorn, E. (2012a). 'Everyone wants to be like Harvard' - or do they? Cherishing all Missions Equally', In: Curaj, A., Scott, P., Vlăsceanu, L. and Wilson, L. (Eds.), European Higher Education at the crossroads: between the Bologna Process and national reforms, Volume 2, Dordrecht: Springer, 837-862. 
Hazelkorn, E. (2012b). 'European 'transparency instruments': Driving the Modernisation of European Higher Education'. In: Curaj, A., Scott, P., Vlăsceanu, L. and Wilson, L. (Eds.), European Higher Education at the crossroads: between the Bologna Process and national reforms, Volume 1, Dordrecht: Springer, 339-360.

Hazelkorn, E. (2014). 'Rebooting Irish Higher Education: Policy Challenges for Challenging Times', Studies in Higher Education, 39(8), 1343-1354.

Hazelkorn, E. (2015). Rankings and the Reshaping of Higher Education. The Battle for World-Class Excellence. Basingstoke: Palgrave Macmillan.

Hazelkorn, E. (2016). Towards 2030: A Framework for Building a World-Class PostCompulsory Education System for Wales. Review of the oversight of post-compulsory education in Wales, with special reference to the future role and function of the Higher Education Funding Council for Wales (HEFCW). Report to the Welsh Government. Cardiff: Welsh Government. Accessed 4 November 2016, http://gov.wales/docs/dcells/publications/160310-hazelkorn-report-en.pdf

Hazelkorn, E. and Gibson, A. (2016). 'IRELAND: Valuing the Arts and Humanities in a Time of Crisis and Beyond' in P. Benneworth, M. Gulbrandsen and E. Hazelkorn The Impact and Future of Arts and Humanities Research. Basingstoke: Palgrave Macmillan. In Press.

Hazelkorn, E. et al. (2015). Science Education for Responsible Citizenship. Report of the Expert Group On Science Education. Brussels, Belgium: Directorate-General for Research and Innovation Science with and for Society. http://doi.org/10.2777/12626

Hazelkorn, E., Gibson, A. and Harkin, S. (2015). 'Irish higher education from massification to globalisation: reflections on the transformation of Irish higher education', In: K. Rafter and M. O'Brien (Eds.) The State in Transition. Essays in Honour of John Horgan. Dublin: O’Brien Press, 235-260.

HEA (2013). 'Guidelines for completion of mission-based performance compacts', Dublin: Higher Education Authority. Accessed 4 November 2016, from http://www.hea.ie/sites/default/files/2. guidelines for completion of compact.pdf

HEA (2015). Towards A Performance Evaluation Framework: Profiling Irish Higher Education 2012-2013. Dublin: Higher Education Authority. Accessed 4 November 2016, from http://www.hea.ie/sites/default/files/institutional_profiles 201213 pdf version.pdf

HEA (2016). 'Building World Class Systems of Higher Education: Benchmarking International Experiences and Challenges', System Roundtable, March. Unpublished transcripts. 
HEFCE (2010) 'Public Perceptions of the Benefits of Higher Education'. Bristol and London: Higher Education Funding Council for England. Accessed 14 February 2017, from http://www.hefce.ac.uk/media/hefce/content/pubs/2010/rd2410/rd24_10.pdf

HEQCO (2013) Performance Indicators: A report on where we are and where we are going, Toronto, Higher Education Quality Council of Ontario, http://www.heqco.ca/SiteCollectionDocuments/Performance Indicators ENG.PDF

Heilbroner, R. L., and Thurow, L. (1998). Economics Explained: Everything You Need to Know About How the Economy Works and Where It's Going. New York: Touchstone.

Hicks, M. (2015) Design Questions: Funding Models for Ontario, Toronto, Higher Education Quality Council of Ontario.

Hirsch, F. (1997) The Social Limits to Growth, London: Routledge.

Holley, K. (2006). 'Defining Governance for Public Higher Education in the TwentyFirst Century', In: Tierney, W. (Ed.) Governance and the Public Good. Albany, NY: State University of New York Press.

ICSTI (2015). Innovation 2020. Dublin: Department of Jobs, Enterprise and Innovation. Accessed 4 November 2016, from https://www.djei.ie/en/Publications/Publication-files/Innovation-2020.pdf

Immerwahr, J. and J. Johnson (2010) Squeeze Play 2010: Continued Public Anxiety on Cost, Harsher Judgments on How Colleges Are Run. Washington D.C. and San Jose: Public Agenda and National Center for Public Policy and Higher Education

Innovation Taskforce (2010). Innovation Ireland. Report of the Innovation Taskforce. Government of Ireland, Dublin. Accessed 4 November 2016, from http://www.enterprise-ireland.com/en/AboutUs/News/Report\%20of\%20the\%20innovation\%20task\%20force.pdf

Ipsos MORI Social Research Institute (2010). Public perceptions of the benefits of higher education, Bristol: HEFCE. Accessed 4 November 2016, from http://www.hefce.ac.uk/media/hefce/content/pubs/2010/rd2410/rd24 10.pdf

Jaschik, S. (2015, 20 January). 'Well-prepared in their own eyes', Inside Higher Ed. Accessed 4 November 2016, from https://www.insidehighered.com/news/2015/01/20/study-finds-big-gaps-betweenstudent-and-employer-perceptions

Kaiser, F., Maassen, P., Meek, V.L., van Vught, F.A., de Weert, E. and Goedegebuure, L. (Eds.). (1994). Higher Education Policy: An International 
Comparative Perspective, Oxford: International Association of Universities and Pergamon Press.

Kerr, C. (2001). The Uses of the University (5th ed.). Cambridge, Massachusetts: Harvard University Press. Retrieved from http://raley.english.ucsb.edu/wpcontent/uploads/Reading/Kerr.pdf

King, R. (2009). Governing Universities Globally. Organizations, Regulation and Rankings. Cheltenham: Edward Elgar.

Kirk, A. and Scott, P. (2016, 2 November). 'US election: How age, race and education are deciding factors in the race for President', The Telegraph. Accessed 4 November 2016, from http://www.telegraph.co.uk/news/0/us-election-how-age-raceand-education-are-deciding-factors-in-t/

Klemencic, M. (2015). 'Student involvement in quality enhancement', In: Huisman, J., de Boer, H., Dill, D. and Souto-Otero, M. (eds.) The Handbook of Higher Education Policy and Governance. Basingstoke: Palgrave Macmillan.

Lane, J.E. and D. B. Johnstone (eds.) (2013) Higher Education Systems 3.0. Harnessing Systemness, Delivering Performance, Albany: SUNY Press.

Lijphardt, A. (1975) The Politics of Accommodation: Pluralism and Democracy in the Netherlands, $\left(2^{\text {nd }}\right.$ rev. ed.). Berkeley, CA: University of California Press.

Lijphart, A. (2012). Patterns of Democracy (Revised). New Haven, CT: Yale University Press.

Lumina Foundation (2013) America's Call for Higher Education Redesign. Study of the American Public's Opinion on Higher Education. Indianapolis: Lumina Foundation. Accessed 14 February 2017, from http://www.luminafoundation.org/publications/Americas Call for Higher Education Redesign.pdf

Magna Charta (1988). 'MAGNA CHARTA UNIVERSITATUM', Accessed 4 November 2016, from http://www.magna-charta.org/resources/files/the-magnacharta/english

Marginson, S. (2016a). Higher Education and the Common Good. Manchester: Manchester University Press.

Marginson, S. (2016b). Public/private in higher education: a synthesis of economic and political approaches. Centre for Global Higher Education working paper series, No. 1. Accessed 2 March 2017, from http://www.researchcghe.org/perch/resources/publications/wp1.pdf 
Marginson, S. (2011). 'Higher education and public good', Higher Education Quarterly, 65 (4), 411-433.

Massaro, V. (2010) 'Cui bono? The relevance and impact of quality assurance,' Journal of Higher Education Policy and Management, 32(1), 17-26.

McMahon, Walter W. (2009), Higher Learning, Greater Good: The Private and Social Benefits of Higher Education, Baltimore, MA: John Hopkins University Press.

Meek, V. (2003). Market coordination, research management and the future of higher education in the post-industrial era. 2nd Meeting of the UNESCO Regional Scientific Committee for Asia and the Pacific, 2003(5).

Miao, K. (2012) Performance-based Funding of Higher Education. A Detailed Look at Best Practices in 6 States. Washington, D.C.: Center for American Progress.

MoECS - Dutch Ministry of Education, Culture, and Science (2011) Quality in Diversity: Strategic Agenda for Higher Education, Research and Science, Accessed 4 November 2016, from https://www.government.nl/documents/reports/2012/08/30/quality-in-diversity

MoECS - Dutch Ministry of Education, Culture, and Science (2015a) The Value of Knowledge: Strategic Agenda for Higher Education and Research 2015-2025, Accessed 4 November 2016, from https://www.government.nl/binaries/government/documents/reports/2015/07/01/thevalue-of-knowledge/the-value-of-knowledge.pdf

MoECS - Dutch Ministry of Education, Culture, and Science (2015b) 'Wetenschappelijke krachten bundelen voor topprestaties', Accessed 4 November 2016, from https://www.rijksoverheid.nl/ministeries/ministerie-van-onderwijs-cultuuren-wetenschap/nieuws/2015/11/27/wetenschappelijke-krachten-bundelen-voortopprestaties

Morgan, W. J., and White, I. (2014). 'The Value of Higher Education: public or private Public or Private Good?' Weiterbildung, (November).

Morrell, K. (2009) 'Governance and the Public Good', Public Administration, 87(3): 538-56.

Moynihan, A. (2016). Normative Isomorphism: Is Irish academic work-life the same in different institutional types in the universal phase of higher education? PhD Thesis, Dublin: Dublin Institute of Technology.

Neave, G. (1998). 'The Evaluative State Reconsidered', European Journal of Education, 33(3), 265-284. 
New Zealand Productivity Commission (2016) 'New Models of Tertiary Education Draft Report', Wellington. Accessed 14 February 2017, from

http://www.productivity.govt.nz/inquiry-content/2683?stage=3

O'Connor, J. (1973). The Fiscal Crisis of the State. New York: St. Martin's Press.

OECD (2006) Competitive Cities in the Global Economy, Paris: Organisation of Economic Co-operation and Development.

OECD (2014a) Education at a Glance, Paris: OECD, p150. 'With few exceptions, the net private returns related to a tertiary education exceed those of upper secondary or post-secondary non-tertiary education.'

OECD (2014b) Innovation Policy Review the Netherlands. Paris: Organization for Economic Cooperation and Development.

Pickstone, J.V. (2000) Ways of knowing: A new history of science, technology and medicine. Manchester: Manchester University Press.

Public Agenda (2016, 12 September) ‘Public Opinion on Higher Education', http://www.publicagenda.org/pages/public-opinion-higher-education-2016

Pusser, B. (2006) 'Reconsidering Higher Education and the Public Good: The Role of Public Sphere'. In: Tierney, W. (Ed.) Governance and the Public Good. Albany, NY: State University of New York Press, 11-27.

Rammell, B. (2016) Protecting the Public Interest in Higher Education. Occasional Paper 15. Oxford: Higher Education Policy Institute (HEPI).

Robertson, S. L. (2006). 'Globalisation, GATS and Trading in Education Services', In J. Kallo and R. Rinne (Eds.), Supranational Regimes and National Education Policies: Encountering Challenge. Helsinki, Finland: Finnish Education Research Association. Retrieved from

http://www.bris.ac.uk/education/research/centres/ges/publications/04slr.pdf

Rowland, F. (2002). 'The peer-review process.' Learned Publishing, 15, 247-258. Slaughter, S. and Leslie, L. (1997). Academic Capitalism. Politics, Policies and the Entrepreneurial University. Baltimore, MD: Johns Hopkins University Press.

Stiglitz, J. (1999) 'Knowledge as a global public good'. In I. Kaul, I. Grunberg, and M. A. Stern (Eds.), Global public goods: International cooperation in the 21st century. New York: The United Nations Development Programme.

Taylor, M. Z. (2016). The Politics of Innovation. Oxford: Oxford University Press.

Thaler, R. H., and Sunstein, C. R. (2009). Nudge. London: Penguin. 
Tierney, W. (2006). 'The Examined University. Process and Change in Higher Education'. In: Tierney, W. (Ed.) Governance and the Public Good. Albany, NY: State University of New York Press.

Trow, M. (1974). 'Problems of the Transition from Elite to Mass Higher Education', Reprinted in Burrage, M. (Ed). Martin Trow. Twentieth-Century Higher Education. From Elite to Mass to Universal. Baltimore, MD: Johns Hopkins University Press. U-Map (n.d.) 'U-Map, the European Classification of Higher Education Institutions', Accessed 4 November, from http://www.u-map.eu

US Department of education (2015, 6 November) 'Department of Education Advances Transparency Agenda for Accreditation', Washington, D.C., Accessed 4 November 2016, from https://www.ed.gov/news/press-releases/departmenteducation-advances-transparency-agenda-accreditation

Usher, A. (2015). Stop Saying Higher Education is a Public Good. Retrieved March 11, 2015, from http://campaign.r20.constantcontact.com/render?ca=c0b67691-7e61474e-b9bf-fb39d675de55\&c=11752f80-b6e7-11e3-b5e7d4ae5292c40b\&ch=11f50de0-b6e7-11e3-b697-d4ae5292c40b

Van Vught, F. (2007). 'Diversity and differentiation in higher education systems'. Conference presentation, Cape Town. Retrieved from http://docs.china-europaforum.net/doc 759.pdf

Van Vught, F.A. (ed.) (1989) Governmental Strategies and Innovation in Higher Education, Higher Education Policy Series. London: Jessica Kingsley Publishers. Warren, E. (2016, 22 September) 'Senators Warren, Durbin and Schatz Introduce Bill to Reform Higher Education Accreditation and Strengthen Accountability for Students and Taxpayers', Washington, D.C., https://www.warren.senate.gov/?p=press release\&id=1249

Weingarten, H., Hicks, M., Jonker, L., Smith, C. and Arnold, H. (2015) Canadian Postsecondary Performance: Impact 2015, Toronto, Higher Education Quality Council of Ontario, http://www.heqco.ca/SiteCollectionDocuments/HEQCO Canadian Postsecondary Performance Impact2015.pdf

Williams, K. (2016, 12 September) 'Universities must reflect on gulf between campus and community exposed by Brexit', Times Higher Education,

https://www.timeshighereducation.com/blog/universities-must-reflect-gulf-betweencampus-and-community-exposed-brexit

Ziskin, M., Hossler, D., Rabourn, K., Cekic, O. and Hwang, Y. (2014) Outcomes Based Funding: Current Status, Promising Practices and Emerging Trends, Toronto: Higher Education Quality Council of Ontario, 17-18. Accessed 4 November 2016, 
from http://heqco.ca/SiteCollectionDocuments/Outcomes-

Based\%20Funding\%20ENG.pdf

1 This paper was originally written for the 'Presidential Session: Next steps in research on public goods in higher education', ASHE Conference, 9-12 November 2016, Columbus, Ohio. The authors would like to Simon Marginson, who made thoughtful comments and suggestions. All errors and omissions are ours.

${ }^{2}$ Centre for Global Higher Education, UCL Institute of Education, London, and Higher Education Policy Research Unit (HEPRU), Dublin Institute of Technology, Ireland

${ }^{3}$ Centre for Global Higher Education, UCL Institute of Education, London; Higher Education Policy Research Unit (HEPRU), Dublin Institute of Technology, Ireland; Cultures, Academic Values and Education Research Centre (CAVE), School of Education, Trinity College Dublin, Ireland.

${ }^{4}$ The discourse around 'engagement' and 'global' arguably attempts to reunite these tensions - and have been led variously by the academy, higher education institutions and the government. See broader discussion of these issues by Hazelkorn in Goddard et al., 2016.

5 'The university is an autonomous institution at the heart of societies differently organised because of geography and historical heritage; it produces, examines, appraises and hands down culture by research and teaching. To meet the needs of the world around it, its research and teaching must be morally and intellectually independent of all political authority and intellectually independent of all political authority and economic power.' Quoted in Magna Charta (1988).

6 'In practice, RRI is implemented as a package that includes multi-actor and public engagement in research and innovation, enabling easier access to scientific results, the take up of gender and ethics in the research and innovation content and process, and formal and informal science education.' Europa, RRI.

${ }^{7}$ For example: 'Universities should be funded more for what they do than for what they are, by focusing funding on relevant outputs rather than inputs,...Competitive funding should be based on institutional evaluation systems and on diversified performance indicators with clearly defined targets and indicators supported by international benchmarking' (Europa, 2006); '...Enhance the performance and international attractiveness of Europe's higher education institutions and raise the overall quality of all levels of education and training in the EU...' (Europa, 2010)

8 'Virginia's Higher Education Restructuring Act (2005), for example, enables public universities to apply for one of three levels of autonomy, each with increasing levels of campus responsibility for capital building projects, procurement, personnel, and tuition and fees. In exchange, campuses agree to commit them- selves to achieving state goals for access, affordability, and student retention; the institution is obligated 
to develop stronger articulation agreements with community colleges, stimulate economic development, attract externally funded research, and meet financial and administrative management standards. This legislation was based on a proposal developed by three of the state's leading research universities, and the final bill attracted large majorities in both houses of the legislature.' Extract from Dee, 2006, 137 
Centre for Global Higher Education UCL Institute of Education London WC1H OAL

www.researchcghe.org @ResearchCGHE 